\title{
Parental factors associated with walking to school and participation in organised activities at age 5: Analysis of the Millennium Cohort Study
}

\author{
Sinead Brophy ${ }^{1 *}$, Roxanne Cooksey ${ }^{1}$, Ronan A Lyons ${ }^{1}$, Non E Thomas ${ }^{2}$, Sarah E Rodgers ${ }^{1}$, Michael B Gravenor ${ }^{1}$
}

\begin{abstract}
Background: Physical activity is associated with better health. Two sources of activity for children are walking to school and taking part in organised sports and activities. This study uses a large national cohort to examine factors associated with participation in these activities.

Methods: The Millennium Cohort study contains 5 year follow-up of 17,561 singleton children recruited between 2000-2002 in the UK. All participants were interviewed in their own homes at 9 months, 3 years and 5 years follow-up and all measures were self reports. Logistic regression and likelihood ratio tests were used.

Results: Children are less likely to walk to school as income and parental education increase [Adjusted odds: 0.7 (95\%Cl: 0.6-0.8) for higher income/education compared to low income/no qualifications]. However, if the parent plays with the child in high income families the child is more likely to walk to school [Adjusted odds: 1.67 (95\%Cl: 1.3-2.1)]. Children taking part in organised activities are from higher income, higher education families, with a car, in a "good" area with non-working mothers. However, in low socio-economic families where the parent plays with the child the child is more likely to take part in organised activities [Adjusted odds: 2.0 (95\% Cl: 1.5-2.7)].

Conclusions: Income is an important determinant of the type of activity available to children. Families that report good health behaviours (non-smoking, low TV viewing) and play with their children show higher levels of physical activity. Thus, parenting practice appears to have a strong impact on their child's physical activity.
\end{abstract}

\section{Background}

Levels of physical activity in children are declining [1-4] while childhood obesity is receiving increasing attention [5-7] and reported to have doubled over the last two decades in the UK [8]. There is overwhelming evidence that sources of physical activity, such as walking to school, which can form a routine activity built into the normal day, are dramatically declining [9-12]. Participation in activity is associated with positive self beliefs and better long term health including improved cardiovascular and musculoskeletal fitness and weight reduction [13-15]. However, physical activity and fitness levels are declining among young people with time $[2,12]$. This change in levels of activity can have long term implications as physical activity levels are thought to be

\footnotetext{
* Correspondence: s.brophy@swansea.ac.uk

${ }^{1}$ Centre for Health Information, Research and Evaluation, School of Medicine,

Swansea University, Singleton Park, Swansea, Wales, SA2 8PP, UK

Full list of author information is available at the end of the article
}

developed from a young age and behaviours established when young persist into adulthood [16]. Therefore, it is crucial to target and increase physical activity levels of children in order for health benefits to be gained over a lifetime. Changes in society have led to children having less independent play outside, more TV viewing and motorised travel. Additionally, concerns regarding safety and injury for the child mean that more children spend their time supervised [17].

Most research to date has focused on older children (aged 9+) and adolescents [18-21] and have been conducted in urban areas in the U.S. and Australia, which are both countries with urban design not commonly found in other regions such as Europe. In addition, many studies have focused on predominantly white children. Thus, there is a need to examine different regions, younger ages and to include ethnic minority children, as obesity rates vary with ethnicity [22-25]. This study uses existing data from the Millennium cohort study to 
examine factors associated with activity in children in the UK aged 5 (first year in school) who are very strongly reliant on parents to walk them to school and take them to supervised activities, to the park and to play with them. The aim is to inform the development of interventions to improve physical activity levels in younger children with a focus on ethnic minority children.

\section{Methods}

\section{Millennium Cohort Study}

This study used data collected by the Millennium Cohort Study (MCS) [19] which is described in detail in online technical reports [19]. The MCS follows the lives of a sample of 18,552 babies born between 1 September 2000 and 31 August 2001 in England and Wales, and between 22 November 2000 and 11 January 2002 in Scotland and Northern Ireland. Families with children who were living in the UK at age 9 months and eligible to receive Child Benefit at that age were invited to participate (72\% response rate)[26]. Subsequent interviews were carried out at the second contact ( $78 \%$ response rate) and third contacts (79.2\% response rate) when children were approximately 3 and 5 years of age, respectively [27]. A stratified cluster sampling framework was employed to adequately represent families from disadvantaged areas and ethnic minority groups [26]. Parents were interviewed in the home and over $99 \%$ of the main respondents interviewed were the natural mothers [28]. Data from each of the three surveys were obtained from the UK Data Archive, University of Essex.

Sub-group of children examined: Only the singleton children (of the 18,552 children recruited at the first sweep of the MCS) were included within this study. The ethnic group of the child was recorded at the first contact using the 11 Category Census Classification (UK) and only children designated to either White, Asian or African ethnic group were included in the study ( $\mathrm{n}=$ 17,561). The group defined as Asian included families recorded as; Indian, Pakistani, Bangladeshi and Other Asian, the group defined as African included families recorded as Black Caribbean, Black African and Other Black. The child's BMI (weight $(\mathrm{kg})$ )/(height in meters) 2) was measured by trained interviewers and classified using the International Obesity Task Force (IOTF) cutoffs for BMI which are age and sex specific [24].

\section{Outcomes and potential risk factors}

Factors associated with walking to school and/or structured activities were divided into categories of: demographic variables, socio-economic variables, housing and area, parental factors and factors associated with the child (Table 1). All the variables were collected from self-report by the respondent (usually the mother) and no independent measurements of activity (e.g. accelerometer readings or physical activity questionnaires) were performed. Details of data collection are published elsewhere $[26,27]$. Only those who participated at age 5 were analysed. Outcomes were based on questionnaire reports completed by the primary carer, about the child walking to school, and of the number of days per week the child takes part in organised sports or activities. Factors examined are given in Tables 2 and 3.

\section{Statistical analysis}

STATA release 8 was used for all analysis. Factors associated with child activity were examined for evidence of confounding or interaction with parental income and length of time in education (as measures of socioeconomic status) and ethnic background (White/European, South Asian or African), using Mantel-Haenszel tests followed by regression analysis using likelihood ratio tests. Logistic regressions were performed using all factors associated with activity in an initial unadjusted analysis and likelihood ratio tests were used to build the adjusted model. Interaction terms for variables in the adjusted model were examined using likelihood ratio tests. Goodness of fit was assessed using the Hosmer and Lemeshow statistic [29]. Risk ratios for subgroups were also calculated to facilitate interpretation of findings.

\section{Results}

\section{Walking to school}

Children were less likely to walk to school as income and education levels of the primary carer increased [Odds ratio: 0.7 (0.6-0.8) see Tables 2 and 4]. Walking to school was more likely if the primary carer was not working, the family did not have access to a car, and if the child lived in an urban area (as opposed to a village) [See Table 4]

However, in physically active high income families (i.e. children who were from higher income families and who took part in organised sports) children were also likely to walk to school [odds ratio 1.7 (95\%CI 1.3-2.1) See Table 4]. Thus, children are more likely to walk to school if they are from low income backgrounds, or are active affluent children [See Table 4]. Factors associated with walking to school are given in Figure 1.

\section{Organised sports and activities}

Children from ethnic minority groups, those with no access to a car, from larger families, with a working mother, an overweight mother and in a family with poor health behaviours (smoking, watching $>3$ hour TV) were less likely to participate in organised exercise [Tables 3 and 5]. Children who were more likely to take part in organised activities were; girls, those with higher school 
Table 1 Variables examined

\begin{tabular}{|c|c|c|}
\hline Variable & Sweep of data collection & Units of analysis \\
\hline \multicolumn{3}{|l|}{ Demographic variables } \\
\hline Sex & First & Male or female \\
\hline Ethnic Group & First & $\begin{array}{l}\text { White, Asian (includes Indian, Pakistani, Bangladeshi and } \\
\text { other Asian), African (includes Black Caribbean, Black } \\
\text { African, Other Black) }\end{array}$ \\
\hline Number in household & First & Number reported \\
\hline \multicolumn{3}{|l|}{ Socio-economic variables } \\
\hline Family Income & First & $\begin{array}{l}\text { Per annum: } \\
<£ 10,400 \text {, } \\
£ 10,400-£ 20,800 \\
>£ 20,800\end{array}$ \\
\hline Highest academic qualification & First & None, GCSE/O'level, A'level, University degree or higher \\
\hline Access to car or van & Second & Yes or no \\
\hline In work & Third & Yes or no \\
\hline \multicolumn{3}{|l|}{ Housing/Area } \\
\hline Good area to raise children & Third & Poor, good or excellent \\
\hline Area/setting & First and second & Urban, town or village \\
\hline Type of accommodation & Second and third & House/bungalow or Flat/maisonette \\
\hline Access to garden & First, second and third & Yes or no \\
\hline Perceived safety of area & Third & Safe, moderate, unsafe \\
\hline \multicolumn{3}{|l|}{ Parental factors } \\
\hline Age of respondent & Third & Age reported \\
\hline Respondent general health & Third & Excellent, very good, good, fair or poor \\
\hline Anyone smoke near child & Third & Yes or no \\
\hline \multicolumn{3}{|l|}{ Child factors } \\
\hline BMl of child & Third & BMI score reported \\
\hline Parental assessment child behaviour (SDQ) & Third & SDQ score reported \\
\hline Bracken score & Second & Bracken score reported \\
\hline Exercise outside school at a club or class & Third & $1=$ Once a week, $0=$ Less than once a week \\
\hline Walk or cycle to school & Third & Yes or no \\
\hline Sport with parent & Third & $1=$ Once a week, $0=$ Less than once a week \\
\hline Plays physically active games with parent & Third & $1=$ Once a week, $0=$ Less than once a week \\
\hline Go to playground with parent & Third & $1=$ Once a week, $0=$ Less than once a week \\
\hline Hours television watched per day & Third & Less that 3 hours or more than 3 hours \\
\hline
\end{tabular}

readiness scores, those with younger parents, where the mother has a higher educational achievement level, higher income families and children in excellent areas to raise a child. However, maternal education plays a role. When maternal education is high, parents who play sports with their child are less likely to bring their child to organised clubs. Yet, when the mother has no qualifications, but the family play sports with their child, they are also more likely to bring their child to organised sports and clubs. The proposed model for factors associated with taking part in organised activity is given in Figure 2.

\section{Goodness of fit}

Goodness of fit assessment showed no significant difference between the models and the observed data, confirming a good fit of both model to the data $(p=0.43$ for Table 4 and $\mathrm{p}=0.46$ for Table 5 ).

\section{Discussion}

This study examines the factors associated with walking to school and taking part in organised activities. Findings show that income is an important factor in determining the pattern of child activity levels at age 5 . In general, walking to school is associated with lower income, while taking part in organised sports is associated with higher income. However, this finding is for children aged 5 and does not appear to be the same as that seen in older children, where more deprived children are reported to be less likely to walk $[18,30]$. However, this negative association for older children is not supported by all the literature [19]. For younger children (aged 5), it appears, with increasing income, the type of activity is exchanged from a free but time consuming activity (as most 5 year olds need to be accompanied to school if walking), to a time saving but fee paying 
Table 2 Crude odds of factors associated with walking to school

\begin{tabular}{|c|c|c|c|}
\hline Variable & $\begin{array}{l}\% \text { walking to school in the } \\
\text { exposed group }\end{array}$ & $\begin{array}{l}\% \text { walking to school in the } \\
\text { unexposed group }\end{array}$ & $\begin{array}{l}\text { Odds ratio * (exposed/ } \\
\text { unexposed) }\end{array}$ \\
\hline \multicolumn{4}{|l|}{ Demographics } \\
\hline Male/Female & Male: 50.7\% (3538/6976) & Female: $50.5 \%$ (3369/6671) & - \\
\hline Ethnic group & African/Asian: 60.5\% (1071/1770) & White: 49.1\% (4356/8729) & 1.59 (95\%Cl: 1.4-1.75) \\
\hline Number in household & More than 4: 51.8\% (2551/4918) & Four or less: $49.9 \%(4356 / 8729)$ & 1.04 (95\%Cl: $1.02-1.07)$ \\
\hline \multicolumn{4}{|l|}{ Socio-economics } \\
\hline Family income & Low 62\% (1930/3113) & $\begin{array}{l}\text { Medium: 53\% (2208/4157) } \\
\text { High: } 41 \%(3089 / 5283)\end{array}$ & 1.5 (95\%Cl: 0.1.45-1.59) \\
\hline Academic achievement & $\begin{array}{l}\text { None: } 64 \%(1508 / 2339) \\
\text { O'level: 52\% (3121/6059) }\end{array}$ & $\begin{array}{l}\text { A'Level: 47\% (634/1336) } \\
\text { Uni :40\% (1431/3542) }\end{array}$ & 1.6 (95\%Cl: $1.56-1.79)$ \\
\hline Access to car & Have a car: 45.9\% (4844/10559) & No access to car: $78.5 \%(1339 / 1706)$ & 0.23 (95\%Cl: $0.21-0.26)$ \\
\hline Primary carer in work & In work: 44\% (3430/7815) & Not in work: 60\% (3477/5831) & 0.53 (95\% Cl: $0.50-0.57)$ \\
\hline \multicolumn{4}{|l|}{ Area } \\
\hline Good area to raise children & Excellent:47.2\% (4592/9717) & $\begin{array}{l}\text { Moderate: 58\% (1696/2939) } \\
\text { Poor/very poor: 62.9\% (607/964) }\end{array}$ & 0.62 (95\% Cl: 0.58-0.67) \\
\hline Area/Setting & Urban: $54.5 \%(4868 / 8926)$ & $\begin{array}{l}\text { Town: } 48.8 \%(421 / 862) \\
\text { Village: } 37.9 \%(266 / 702)\end{array}$ & 1.5 (95\%Cl: $1.37-1.7)$ \\
\hline Perceived safety of area & Very safe: 49\% (5798/11779) & Moderate-not safe: 59\% (1095/1846) & 0.66 (95\%Cl: 0.6-0.7) \\
\hline \multicolumn{4}{|l|}{ Parents } \\
\hline Age of primary carer & More than 35 yrs: 45.4\% (2563/5651) & $\begin{array}{l}\text { Less than or equal to } 35 \text { yrs: } 54.3 \% \\
(4344 / 7996)\end{array}$ & 0.7 (95\%Cl: 0.65-0.74) \\
\hline Health of primary carer & Good: 50.3\% (6659/13,231) & Poor: 59.1 (240/406) & $0.7(0.57-0.86)$ \\
\hline BMI of primary carer & More than $25: 49.9 \%(2355 / 4717)$ & $\begin{array}{l}\text { Less than or equal to } 25: 49.1 \% \text { (3499/ } \\
7114 \text { ) }\end{array}$ & - \\
\hline Smokes near child & Smokes: 59.7\% (1167/1954) & Does not smoke: 49\% (787/6736) & 1.53 (95\% Cl: 1.4-1.7) \\
\hline \multicolumn{4}{|l|}{ Child } \\
\hline $\begin{array}{l}\text { BMI of child (overweight/obese } \\
\text { according to Obesity Taskforce } \\
\text { definition) }\end{array}$ & $\begin{array}{l}\text { Overweight/obese: } 50.3 \% \text { (1466/ } \\
\text { 2914) }\end{array}$ & Not overweight/obese: 50.7 (5345/10548) & - \\
\hline Bracken School Readiness Score & Less than $3: 56.3 \%(2273 / 4037)$ & More or equal to 3: $48.2(4634 / 9610)$ & 1.38 (95\%Cl: $1.2-1.5)$ \\
\hline $\begin{array}{l}\text { Strengths and Difficulties Questionnaire } \\
\text { total }>7\end{array}$ & More than 7: 54.4\% (3695/6786) & Less or equal to $7: 46.8 \%(3212 / 6907)$ & 1.35 (95\%Cl: $1.3-1.45)$ \\
\hline Taking part in organised sports/exercise & Organised sport: 45.5\% (3223/6906) & No organised sport: 56.1\% (3683/6562) & 0.65 (95\%Cl: $0.61-0.70)$ \\
\hline Plays sports (with parent) & $\begin{array}{l}\text { Plays sport with parent: } 50.0 \% \text { (4667/ } \\
9341)\end{array}$ & $\begin{array}{l}\text { Does not play sport with parent: } 52.0 \% \\
(2239 / 4305)\end{array}$ & 0.92 (95\%Cl: 0.85-0.99) \\
\hline $\begin{array}{l}\text { Playing physically active games (with } \\
\text { parent) }\end{array}$ & Plays games: 50.6\% (4145/8190) & $\begin{array}{l}\text { Does not play games: } 50.58 \% \text { ( } 2757 / \\
5451 \text { ) }\end{array}$ & - \\
\hline Going to playground (with parent) & $\begin{array}{l}\text { Goes to play ground: } 52.7 \% \text { (4469/ } \\
8469)\end{array}$ & $\begin{array}{l}\text { Does not go to playground: } 47.1 \% \\
(2432 / 5167)\end{array}$ & 1.25 (95\%Cl: $1.17-1.3)$ \\
\hline More than 3 hours of TV per day & More than 3 hours: 56\% (1145/2042) & Less than 3 hours: 49.6\% (5758/11599) & $1.29(1.17-1.4)$ \\
\hline
\end{tabular}

* The tables are set out so that the exposed group is always compared to the unexposed group. For example, on table 2 exposures is taken as being of an ethnic minority group - so exposed/unexposed would be the proportion walking in the exposed group (ethnic minority) divided by the proportion walking in the unexposed group (white).

activity. Interviews with older children (10-11 year olds) also suggest that physical activity for children in higher socio-economic schools is based around sports clubs, with parents providing financial support and transport to clubs, while, children from lower socioeconomic background have more unstructured play in the street and are verbally encouraged to "go out and do something" [31]. This swapping of activity may have implications when developing new interventions to increase physical activity in children. For example, interventions which encourage uptake of after school sports may have an effect of decreasing walking and overall activity levels may remain stable. Total activity for the individual would need to be considered in any evaluation of interventions aimed at improving any particular aspect of activity.

There are some families who appear to have high levels of general activity as measured by walking to school, playing organised sports and playing with the child. Activity levels were higher in families with evidence of good health behaviours (non-smoking, low BMI of mother, few hours of TV viewing) and those 
Table 3 Crude odds for factors associated with taking part in organised exercise

\begin{tabular}{|c|c|c|c|}
\hline Variable & $\begin{array}{l}\% \text { taking part in organised activity in } \\
\text { the exposed group }\end{array}$ & $\begin{array}{l}\% \text { taking part in organised activity in } \\
\text { the unexposed group }\end{array}$ & $\begin{array}{l}\text { Odds ratio (exposed/ } \\
\text { unexposed) }\end{array}$ \\
\hline \multicolumn{4}{|l|}{ Demographics } \\
\hline Male & Male: 48.3\% (3436/7112) & Female: 55.39\% (3750/6770) & $0.75(95 \% \mathrm{Cl}: 0.7-0.8)$ \\
\hline Ethnic group & Asian/African: 24.1\% (434/1797) & White: 55.9\% (6752/12085) & 0.25 (95\%Cl: $0.22-0.28)$ \\
\hline Number in household & Greater than 4: 44.6\% (2234/5010) & Equal or less than 4: $55.8(4952 / 8872)$ & 0.64 (95\%Cl:0.59-0.68) \\
\hline \multicolumn{4}{|l|}{ Socio-economics } \\
\hline Family income & Low 31.9\% (1012/3165) & $\begin{array}{l}\text { Medium: } 45.2 \%(1915 / 4234) \\
\text { High: } 69.1 \%(3713 / 5371)\end{array}$ & 0.33 (95\%Cl: $0.3-0.36)$ \\
\hline Academic achievement & $\begin{array}{l}\text { None: } 26.3 \%(627 / 2381) \\
\text { O'level: } 48.8 \%(3000 / 6148)\end{array}$ & $\begin{array}{l}\text { A Level: } 62.5 \%(853 / 1364) \\
\text { Uni: } 71.7 \%(2586 / 3608) \\
\text { A'level: } 7.9 \%(511 / 6435) \\
\text { Uni: } 15.9 \%(1022 / 6435)\end{array}$ & 0.33 (95\% Cl: $0.31-0.36)$ \\
\hline Access to car or van & Access to car: $57.3(6147 / 10736)$ & No access to car: $26.0 \%(453 / 1740)$ & 3.8 (95\%: 3.4-4.2) \\
\hline Employment status & Mother Employed: 61\% (4831/7933) & Mother unemployed: 40\% (2354/5948) & $2.4(2.22-2.56)$ \\
\hline \multicolumn{4}{|l|}{ Area } \\
\hline 'Good' area to raise children & Excellent: 57.4\% (5676/9890) & $\begin{array}{l}\text { Moderate: } 40.5 \% \text { (1208/2985) } \\
\text { Poor/very poor: } 29.9 \% \text { (293/980) }\end{array}$ & $2.2(2.1-2.4)$ \\
\hline Area/Setting & Urban: 47.2\% (4269/9031) & $\begin{array}{l}\text { Town: 60\% (527/876) } \\
\text { Village: 66.6\% (470/706) }\end{array}$ & 0.59 (95\%Cl: $0.5-0.68)$ \\
\hline Perceived safety of area & Very safe: 53.1\% (6939/13081) & Moderate-not safe: $30.8 \%$ (247/801) & $2.5(2.2-2.9)$ \\
\hline Access to garden & $\begin{array}{l}\text { Have access to garden: } 53.3 \%(95 \% \mathrm{Cl} \text { : } \\
6746 / 12653)\end{array}$ & No access to garden: $35.7 \%(435 / 1220)$ & 2.06 (95\%Cl: 1.8-2.3) \\
\hline \multicolumn{4}{|l|}{ Parents } \\
\hline Primary carer $>35$ years of age & Mother added >35: 59.2 (3977/6714) & Mother less than 35 years: 44.8 (3209/7168) & $1.8(95 \% \mathrm{Cl}: 1.7-1.9)$ \\
\hline Health of primary carer & Good: $52.3 \%(7046 / 13459)$ & Fair/poor: 33.1\% (140/423) & $2.2(95 \% \mathrm{Cl}: 1.8-2.7)$ \\
\hline BMl of primary carer $>25$ & $\mathrm{BMI}>25: 50.3 \%(2417 / 4803)$ & $\begin{array}{l}\text { BMI less than or equal to } 25: 55.4 \text { (4009/ } \\
7232 \text { ) }\end{array}$ & 0.81 (95\%Cl: $0.75-0.88)$ \\
\hline Smokes near child & Smokes: 32\% (637/1993) & Does not smoke: 55.1\% (6543/11876) & $0.38(0.34-0.42)$ \\
\hline \multicolumn{4}{|l|}{ Child } \\
\hline BMI of child (overweight) & Child overweight: 51.6\% (1522/2950) & Child not overweight 52.2\% (5604/10742) & 0.98 (95\%Cl: 0.9-1.1) \\
\hline Bracken School Readiness & Score less than 3: $32.5 \%(497 / 1531)$ & Score 3 or more: $54.2(6689 / 12351)$ & 0.4 (95\%Cl: $0.36-0.46)$ \\
\hline $\begin{array}{l}\text { Strengths and Difficulties } \\
\text { Questionnaire total is }>7\end{array}$ & Score more than $7: 42.5 \%(2940 / 6925)$ & Score 7 or less: $61 \%(4246 / 6957)$ & $0.47(95 \% \mathrm{Cl}: 0.44-0.5)$ \\
\hline Walking to or from school & Walks: 46.7\% (3223/6906) & Drives: $57.3 \%$ (3861/6740) & 0.65 (95\%Cl: 0.6-0.7) \\
\hline Plays sports (with parent) & Plays sports: $57.2 \%(5440 / 9530)$ & Does not play sports: $39.9 \%(1746 / 4379)$ & 2.0 (95\%Cl: 0.88-2.2) \\
\hline $\begin{array}{l}\text { Plays physically active games } \\
\text { (with parent) }\end{array}$ & Plays games: $56.4 \%$ (4700/8331) & Does not play games: $44.8 \%$ (2484/5546) & $1.6(95 \% \mathrm{Cl}: 1.5-1.7)$ \\
\hline Go to playground & Goes to playground: $53.8 \%$ (4642/8626) & $\begin{array}{l}\text { Does not go to playground: } 48.4 \% \text { ( } 2537 / \\
5246 \text { ) }\end{array}$ & $1.2(95 \% \mathrm{Cl}: 1.2-1.3)$ \\
\hline More than 3 hours of TV per day & $\begin{array}{l}\text { Watches more than } 3 \text { hours of TV: } 40.7 \% \\
(851 / 2089)\end{array}$ & $\begin{array}{l}\text { Watches less than } 3 \text { hours of TV: } 53.7 \% \\
(6333 / 11788)\end{array}$ & 0.59 (95\%Cl: $0.53-0.65)$ \\
\hline
\end{tabular}

who were more affluent such as having a favourable socio-economic background or living in a 'good' area.

\section{Limitations of the study}

However, how factors are associated with activity can not be fully deciphered from this study. For example, walking to school may be inversely associated with distance to school $[10,32]$ rather than income. Distance to school was not measured in the cohort and is likely to be an important determinant of walking to school. In fact, increasing income may be associated with living in areas that are further away from the school of choice and, therefore, distance to school is likely to be an unmeasured confounder in this study. If distance to school was measured then the volume of active transport (distance and frequency) can also be calculated for each child. Importantly, this study also does not measure activities without the parent. There is no measure of unstructured play in the street (without the parents), and this may be an important source of activity in lower socio-economic children who are not attending clubs and sports. However, in children aged 5 this may have less importance than in older children. This study reports on the parent's opinion of their area which is 
Table 4 Regression analysis. Adjusted odds* for walking to school

\begin{tabular}{lll}
\hline Risk factor & Adjusted Odd ratio & 95\%Cl \\
\hline Education: Primary carer has O'levels (education until age 16, compared to no qualifications) & 0.82 & $0.71-0.94$ \\
Education: Primary carer has A'levels (education until age 18, compared to no qualifications) & 0.75 & $0.62-0.90$ \\
Education: Primary carer has University qualifications (education to age 20+, compared to no qualifications) & 0.69 & 2.79 \\
No access to car or van & 1.39 & $0.59-0.81$ \\
Primary carer is not working & 0.94 & $1.26-1.52$ \\
Living in town (compared to Urban) & 0.71 & $0.80-1.09$ \\
Living in village (compared to urban) & 0.58 \\
Doing organised sports (Low income family) & 1.59 \\
Doing organised sports (Middle income family). & 1.67 \\
Doing organised sports (High income family) & 0.99 \\
Middle income (compared to low income) & 0.73 \\
High income (compared to low income) & 1.18 & $0.60-0.84$ \\
Parent takes child to playground & $1.2-2.0$ \\
\hline
\end{tabular}

Adjusted odds means that they are entered into a regression model together and all the variables are therefore adjusted for the other variables in the model. Factors no longer related to walking to school included: ethnic group, health of parent, smoking near child, Bracken School Readiness Score, Strengths and Difficulties score, watching TV, living in a good area to raise a child, age of parent, playing physically active games, sex ratio, BMI of primary carer.

subjective. There are no objective measurements of the built environment. In addition, this study asks parents how they take their child to school and if they take their child to organised activities. Parents self reported activity may be overestimated and there is no objective validation of the parents self reported activity with the child.

\section{Findings in context with other literature}

This study does add to the debate regarding some previously published recommendations, suggesting priority should be given to lower socioeconomic status populations to facilitate environmental change and safety improvements to improve walking to school [33]. We did not find perceived safety of the area influenced walking (similar to Babey et al [34]). However, this could be because the parents were walking with the children. It is possible that at young ages safety was less of a consideration but it may be an important consideration for parents of older children [35]. Walking to school should be encouraged and targeted in "good" safe areas where working higher income parents live. For example, the Walking School Bus $[36,37]$ may be most useful for the higher income working white families as organising a parent to walk with the child to school may be a barrier for families with both parents working. However, the design of the neighbourhood, distance to school, availability of pavements/sidewalks and ease of connectivity are all important considerations [38].

\section{Recommendations}

In lower socio-economic areas, policies should also try to improve access to organised sports and clubs to encourage and facilitate involvement from ethnic minority and lower income families. It has been reported that

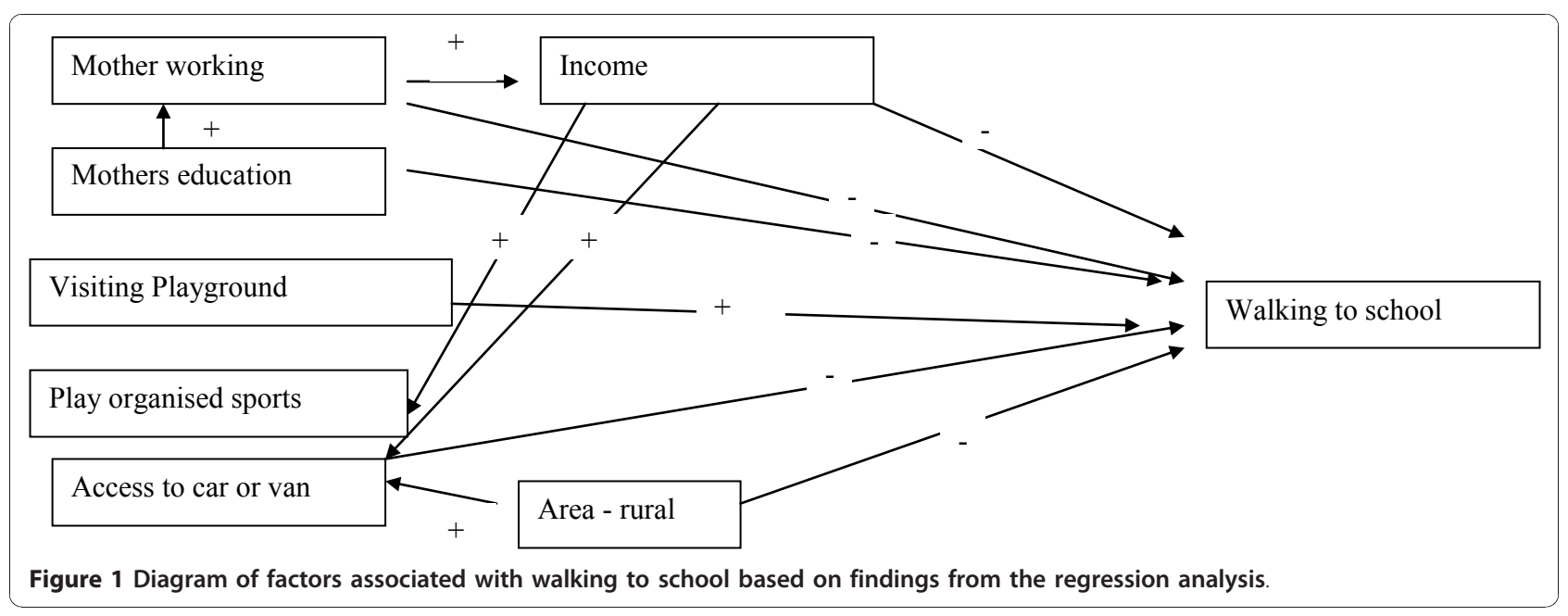


Table 5 Regression analysis. Adjusted odds* of taking part in organised clubs or sports

\begin{tabular}{|c|c|c|}
\hline Risk factor & Adjusted Odd ratio & $95 \% \mathrm{Cl}$ \\
\hline Asian or African Child & 0.43 & $0.35-0.53$ \\
\hline Number in household (change for each additional member of the household) & 0.92 & $0.88-0.96$ \\
\hline Female child & 1.36 & $1.23-1.5$ \\
\hline Education: O'level compared to no qualifications & 1.9 & $1.5-2.5$ \\
\hline Education: A'level compared to no qualifications & 2.5 & $1.8-3.6$ \\
\hline Education: University compared to no qualifications & 3.3 & $2.4-4.5$ \\
\hline No access to car or van & 0.6 & $0.5-0.7$ \\
\hline Working mother & 0.83 & $0.75-0.92$ \\
\hline Middle income compared to low income & 1.1 & $0.96-1.2$ \\
\hline Higher income compared to low income & 1.7 & $1.4-1.9$ \\
\hline Area (comparison average area with poor area to raise a child) & 1.04 & $0.84-1.3$ \\
\hline Area (comparison of 'excellent' area with 'poor' area to raise a child) & 1.4 & $1.12-1.7$ \\
\hline Smoking near child & 0.57 & $0.5-0.67$ \\
\hline Mothers age (under 35 compared to over age 35 ) & 1.13 & $1.03-1.25$ \\
\hline Mother overweight or obese (compared to normal weight) & 0.9 & $0.82-0.99$ \\
\hline School Readiness Score (for each point improvement on score) & 1.22 & $1.1-1.3$ \\
\hline Strengths and Difficulties Questionnaire (for each point increase in difficulties) & 0.97 & $0.96-0.98$ \\
\hline Parent plays with child (no qualifications) & 2.0 & $1.5-2.7$ \\
\hline Parent plays with child (O'level) & 0.62 & $0.45-0.86$ \\
\hline Parent plays with child (A'level) & 0.65 & $0.42-0.99$ \\
\hline Parent plays with child (Uni) & 0.58 & $0.4-0.8$ \\
\hline Plays physically active games & 1.11 & $1.0-1.2$ \\
\hline Takes child to playground & 1.11 & $1.0-1.22$ \\
\hline Child watches more than 3 hour TV per day & 0.85 & $0.74-0.97$ \\
\hline
\end{tabular}

*Adjusted odds means that they are entered into a regression model together and all the variables are therefore adjusted for the other variables in the model. Factors no longer related to participating in activities included; walking to school, perceived safety of area, health of parent, access to a garden, area/setting (urban, rural, village).

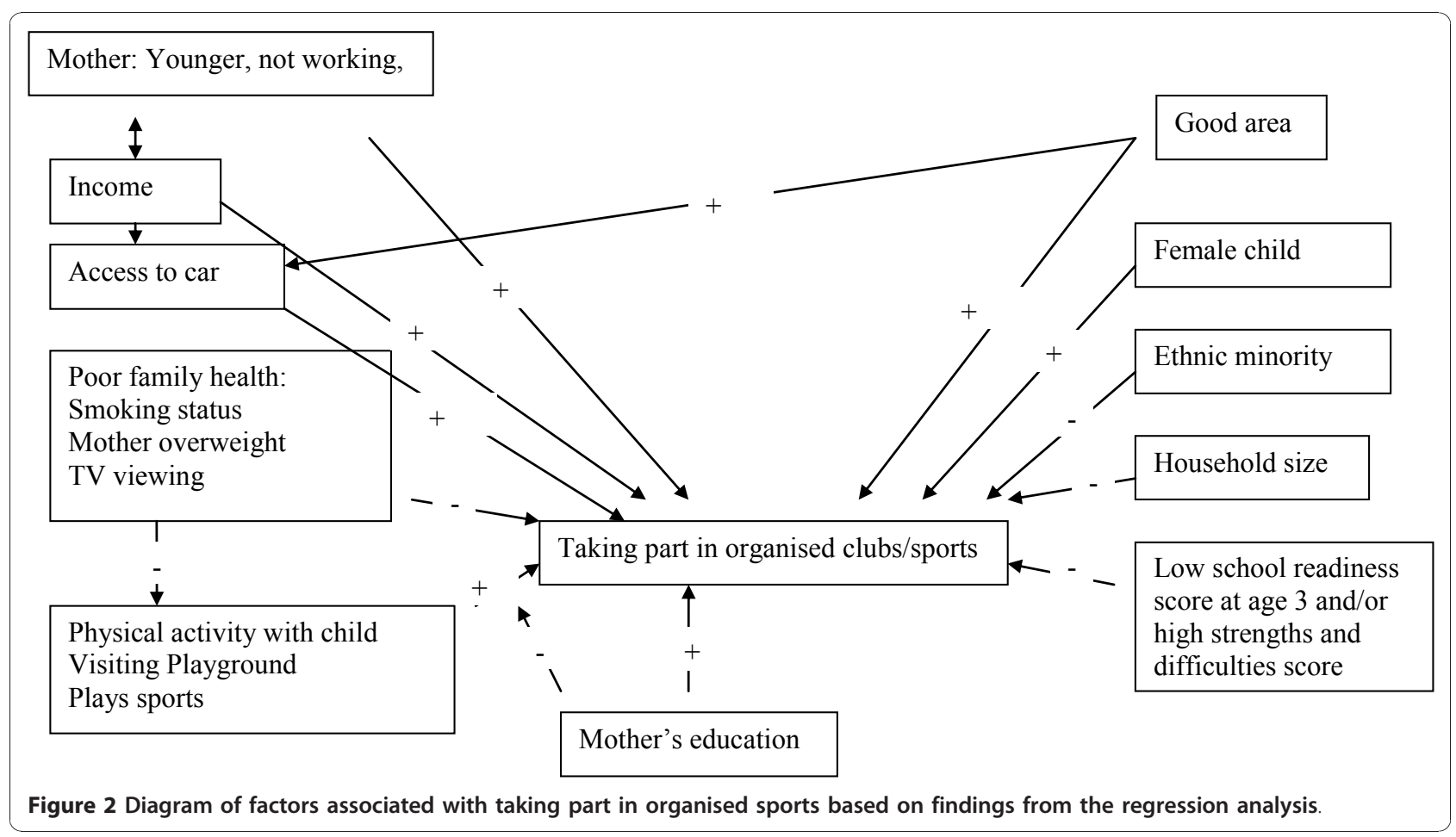


participation in organised clubs/associations is an important part of children's activity, for example, in studies on teenagers this contributes $50-70 \%$ of their total physical activity $[39,40]$. However, participation would be improved if 'the cost was lower' and as cost has been reported to be a significant barrier to families with daughters and on lower income [21]. Thus, helping financially and improving physical access to sports and clubs could encourage parental support. Parental support is an important influence on the child's activity $[41,42]$. Education and playing with the child were found to be linked to both walking to school among higher income families and to involvement in organised sport among lower educational families. Thus, interventions targeted at improving general family health behaviours and support for physical activity appears to be beneficial across all communities. It has been shown [43] that having parents who value vigorous intensity sports provides the most benefits of activity and reduction of sedentary behaviour, while parents valuing household chores has unexpected negative effects (more TV viewing and decreased team participation). Attitudes vary by ethnicity, education, and number of children [43], all factors found to be associated with participation in organised sports/clubs within the MCS. Therefore, more research is needed to examine the family health beliefs and attitudes as predictors of the range of physical activities undertaken by children. Previous research [31] suggests that family based interventions need to accommodate the complex demands of two parent and single parent families and be affordable and varied enough to appeal to a wide range of interests and various ages and development stages of diverse ages of children in the same family.

\section{Conclusions}

In summary, children from families that report adoptions of good health behaviours and engage in play with their children, show higher levels of physical activity. Thus, parenting practices appears to be an important part in the activity levels of children. This may include highlighting the importance of making time for playground visits and playing with your child. For example, there appears to be a time trade-off in some higher income families where parents either take the child to organised sports or play with their child but do not do both. Financially subsidising organised sports and exercise might help lower income families participate in more fee paying organised activities and this should be tested in a randomised controlled trial. However, this is likely to need to be combined with working with families to discuss attitudes and support for increased physical activity. Interventions aimed at one pattern of activity should be tested to ensure other forms of existing activity are not reduced.

List of abbreviations

MCS: Millennium Cohort Study; BMI: Body Mass Index

\section{Acknowledgements}

This study was funded by of the Office of the Chief Social Research Officer (OCSRO) in the Welsh Assembly Government.

\section{Author details}

${ }^{1}$ Centre for Health Information, Research and Evaluation, School of Medicine, Swansea University, Singleton Park, Swansea, Wales, SA2 8PP, UK. ${ }^{2}$ Centre for Child Health, School of Human Sciences, Swansea University, Singleton Park, Swansea, Wales, SA2 8PP, UK.

\section{Authors' contributions}

All authors were involved in designing the research question, SB and RC extracted and analysed the data supervised by MG, all authors read the first drafts of the manuscript, made amendments to the final document and approved the final manuscript.

\section{Competing interests}

The authors declare that they have no competing interests.

Received: 4 May 2010 Accepted: 6 January 2011

Published: 6 January 2011

\section{References}

1. Nader PR: Frequency and intensity of activity of third-grade children in physical education. Arch Pediatr Adolesc Med 2003, 157(2):185-90.

2. Knuth $A G$, Hallal PC: Temporal trends in physical activity: a systematic review. J Phys Act Health 2009, 6(5):548-59.

3. Telama $R$, Yang $X$ : Decline of physical activity from youth to young adulthood in Finland. Med Sci Sports Exerc 2000, 32(9):1617-22.

4. van Mechelen W, Twisk JW, Post GB, Snel J, Kemper HC: Physical activity of young people: the Amsterdam Longitudinal Growth and Health Study. Med Sci Sports Exerc 2000, 32(9):1610-6.

5. Phipps S, Burton P, Lethbridge L, Osberg L: Measuring obesity in young children. Can Public Policy 2004, 30:349-64.

6. Anderson PM, Butcher KR: Childhood obesity: trends and potential causes. Future Child 2006, 16:19-45.

7. National Institute for Health and Clinical Excellence (NICE): Promoting physical activity for children and young people. London: NICE; 2009.

8. Health Survey for England: Obesity and other risk factors in children. 2006, 2: [http://www.ic.nhs.uk/pubs/hse06cvdandriskfactors].

9. Lewis N, Dollman J, Dale M: Trends in physical activity behaviours and attitudes among South Australian youth between 1985 and 2004. J Sci Med Sport 2007, 10(6):418-27.

10. McDonald NC: Active transportation to school: trends among U.S. schoolchildren, 1969-2001. Am J Prev Med 2007, 32(6):509-16.

11. Department of Health and Human Services - Centres for Disease Control and Prevention: Active Transportation to/from School Then and Now Barriers and Solutions. [http://www.cdc.gov/nccdphp/dnpa/kidswalk/ then_and_now.htm], accessed 18 Oct 2010.

12. Tremblay MS, Shields M, Laviolette M, Craig CL, Janssen I, Gorber SC: Fitness of Canadian children and youth: results from the 2007-2009 Canadian Health Measures Survey. Health Rep 21(1):7-20, Mar.

13. Dodge T, Lambert SF: Positive self-beliefs as a mediator of the relationship between adolescents' sports participation and health in young adulthood. J Youth Adolesc 2009, 38(6):813-25.

14. Janz KF, Letuchy EM, Eichenberger Gilmore JM, Burns TL, Torner JC, Willing MC, Levy SM: Early Physical Activity Provides Sustained Bone Health Benefits Later in Childhood. Med Sci Sports Exerc 2009.

15. Morris JN, Hardman AE: Walking to health. Sports Med 1997, 23(5):306-32.

16. Isganaitis E, Levitsky LL: Preventing childhood obesity: can we do it? Curr Opin Endocrinol Diabetes Obes 2008, 15(1):1-8.

17. Gorely T, Biddle SJ, Marshall SJ, Cameron N: The prevalence of leisure time sedentary behaviour and physical activity in adolescent boys: An 
ecological momentary assessment approach. Int J Pediatr Obes 2009, 20:1-10.

18. Panter JR, Jones AP, Van Sluijs EM, Griffin SJ: Neighborhood, route, and school environments and children's active commuting. Am J Prev Med 38(3):268-78, Mar.

19. Harten N, Olds T: Patterns of active transport in 11-12 year old Australian children. Aus N Z J Public Health 2004, 28(2):167-72.

20. Maynard MJ, Baker G, Rawlins E, Anderson A, Harding S: Developing obesity prevention interventions among minority ethnic children in schools and places of worship: The DEAL (DiEt and Active Living) study. BMC Public Health 2009, 9:480.

21. Hardy LL, Kelly B, Chapman K, King L, Farrell L: Parental perceptions of barriers to children's participation in organised sport in Australia. J Paediatr Child Health 2010, 46(4):197-203.

22. Brophy S, Cooksey R, Gravenor MB, Mistry R, Thomas N, Lyons RA, Williams R: Risk factors for childhood obesity at age 5 : analysis of the millennium cohort study. BMC Public Health 2009, 9:467.

23. Saxena S, Ambler G, Cole TJ, Majeed A: Ethnic group differences in overweight and obese children and young people in England: cross sectional survey. Arch Dis Child 2004, 89(1):30-6.

24. Wardle J, Brodersen NH, Cole TJ, Jarvis MJ, Boniface DR: Development of adiposity in adolescence: five year longitudinal study of an ethnically and socioeconomically diverse sample of young people in Britain. Bmj 2006, 332(7550):1130-5.

25. Ogden CL, Flegal KM, Carroll MD, Johnson CL: Prevalence and trends in overweight among US children and adolescents, 1999-2000. Jama 2002, 288(14):1728-32.

26. Plewis I, Calderwood L, Hawkes D, Hughes G, Joshi H: Millennium Cohort Study: Technical Report on Sampling. London; 42007 [http://www. Is.ioe. ac.uk/library.asp?section $=00010001000600060018]$.

27. Hansen K: Millennium Cohort Study First and Second Surveys: A Guide to the datasets. London: University of London; 2006 [http://www.esds.ac. uk/longitudinal/access/mcs/33359.asp].

28. Jaakkola E, Herzberg I, Laiho K, Barnardo MC, Pointon JJ, Kauppi M, Kaarela K, Tuomilehto-Wolf E, Tuomilehto J, Wordsworth BP, Brown MA: Finnish HLA studies confirm the increased risk conferred by HLA-B27 homozygosity in ankylosing spondylitis. Ann Rheum Dis 2006, 65(6):775-80

29. Hosmer D, Lemeshow S: Applied Logistic Regression. New York: John Wiley and Son; 22000.

30. Timperio A, Ball K, Salmon J, Roberts R, Giles-Corti B, Simmons D, Baur LA, Crawford D: Personal, family, social, and environmental correlates of active commuting to school. Am J Prev Med 2006, 30(1):45-51.

31. Thompson JL, Jago R, Brockman R, Cartwright $K$, Page AS, Fox KR: Physically active families - de-bunking the myth? A qualitative study of family participation in physical activity. Child Care Health Dev 2010, 36(2):265-274.

32. Buliung RN, Mitra R, Faulkner G: Active school transportation in the Greater Toronto Area, Canada: an exploration of trends in space and time (1986-2006). Prev Med 2009, 48(6):507-12.

33. Zhu X, Lee C: Correlates of walking to school and implications for public policies: survey results from parents of elementary school children in Austin, Texas. J Public Health Policy 2009, 30(Suppl 1):S177-202.

34. Babey SH, Hastert TA, Huang W, Brown ER: Sociodemographic, family, and environmental factors associated with active commuting to school among US adolescents. J Public Health Policy 2009, 30(Suppl 1):S203-20.

35. Committee on Environmental Health: The Built Environment - Designing Communities to Promote Physical Activity in Children. Pediatrics 2009, 123:1591-8.

36. Pedestrian and Bicycle Information Centre for the Partnership for a Walkable America: icwtWUCoT. Starting a Walking School Bus. 2009 [http://www.walkingschoolbus.org/index.html].

37. Kong AS, Sussman AL, Negrete S, Patterson N, Mittleman R, Hough R: Implementation of a walking school bus: lessons learned. J Sch Health 2009, 79(7):319-25, quiz 33-4.

38. Tester JM: The built environment: designing communities to promote physical activity in children. Pediatrics 2009, 123(6):1591-8.

39. Hardy LL, Kelly B, Chapman K, King L, Farrell L: Parental perceptions of barriers to children's participation in organised sport in Australia. $J$ Paediatr Child Health 46(4):197-203, Apr.
40. Hardy LL, Okely AD, Dobbins TA, Booth ML: Physical activity among adolescents in New South Wales (Australia): 1997 and 2004. Med Sci Sports Exerc 2008, 40(5):835-41.

41. Trost SG, Sallis JF, Pate RR, Freedson PS, Taylor WC, Dowda M: Evaluating a model of parental influence on youth physical activity. Am J Prev Med 2003, 25(4):277-82.

42. Panter JR, Jones AP, van Sluijs EM, Griffin SJ: Attitudes, social support and environmental perceptions as predictors of active commuting behaviour in school children. J Epidemiol Community Health 2010, 64:41-48.

43. Anderson CB, Hughes SO, Fuemmeler BF: Parent-child attitude congruence on type and intensity of physical activity: testing multiple mediators of sedentary behavior in older children. Health Psychol 2009, 28(4):428-38.

\section{Pre-publication history}

The pre-publication history for this paper can be accessed here: http://www.biomedcentral.com/1471-2458/11/14/prepub

doi:10.1186/1471-2458-11-14

Cite this article as: Brophy et al:: Parental factors associated with walking to school and participation in organised activities at age 5: Analysis of the Millennium Cohort Study. BMC Public Health 2011 11:14.

\section{Submit your next manuscript to BioMed Central and take full advantage of:}

- Convenient online submission

- Thorough peer review

- No space constraints or color figure charges

- Immediate publication on acceptance

- Inclusion in PubMed, CAS, Scopus and Google Scholar

- Research which is freely available for redistribution

Submit your manuscript at www.biomedcentral.com/submit
Ciomed Central 